\title{
Autonomous education and its current inclusion in higher education
}

\section{Educación autónoma y su inclusión actual en la educación superior}

\author{
ROMERO-ROMERO, Yair†*, ARAOZ-BALTAZAR, Iván, GARCÍA-PÉREZ, María Laura and \\ VÁZQUEZ-ELORZA, Ariel
}

Centro de Investigación y Asistencia en Tecnología y Diseño del Estado de Jalisco

ID $1^{\text {st }}$ Author: Yair, Romero-Romero / ORC ID: 0000-0002-7779-4211, Researcher ID Thomson: F-1649-2019, CVU CONACYT ID: 239572

\author{
ID $1^{\text {st }}$ Coauthor: Ivan, Araoz Baltazar / ORC ID: 0000-0003-0394-2979, CVU CONACYT ID: 464987 \\ ID $2^{\text {nd }}$ Coauthor: María Laura, García-Pérez / ORC ID: 0000-0002-9897-0069, CVU CONACYT ID: 513590 \\ ID $3^{\text {rd }}$ Coauthor: Ariel, Vázquez-Elorza / ORC ID: 0000-0002-6710-8935, CVU CONACYT ID: 169076
}

DOI: 10.35429/JHEW.2019.5.3.23.24

Received July 30, 2019; Accepted December 30, 2019

\begin{abstract}
Resumen
En este artículo se presenta el estudio comparativo de un aprendizaje autónomo y un aprendizaje autorregulado, su papel en la actualidad dentro de la educación superior y el cómo sus cualidades autónomas deberían ser un factor de interés para los participantes de un proceso de aprendizaje, además de vislumbrar y sugerir el aprendizaje autónomo como una política curricular de la educación superior. Se llevó a cabo mediante una comparación de estrategias realizada en alumnos de nivel licenciatura en una materia específica para homogenizar el contexto. Se realizaron simultáneamente evaluaciones en los diferentes momentos del proceso de aprendizaje que permitieron definir la ventaja de una modalidad sobre otra. Se ubicaron casos de éxito y la efectividad del enfoque autorregulado que hoy en día crece cada vez más con ayuda de las tecnologías de la información y plataformas educativas. Se culmina con una propuesta curricular como parte de los resultados obtenidos de algunas estrategias utilizadas que aumentan la autonomía de pensamiento y de acción con el objetivo de construir un proceso de aprendizaje crítico y universal dentro de los requerimientos competitivos en la sociedad. Es importante reconocer por consiguiente como se lleva a cabo la autonomía y los indicadores necesarios para su puesta en práctica efectiva dentro del cambio de perspectiva de la educación superior.
\end{abstract}

Aprendizaje autónomo, Educación superior, Propuesta curricular

\begin{abstract}
This paper presents the comparative study of Autodidacticism and self-regulated learning, its role in higher education today and how their autonomous qualities should be a factor of interest for participants in a learning process, in addition to suggest autonomous learning as a curricular policy of higher education. It is carried out through a strategies comparison made in undergraduate students in a specific subject to homogenize the context. Evaluations were carried out simultaneously in the different moments of the learning process that allowed defining the advantage of one modality over another. Success cases and the effectiveness of the selfregulated approach were found, wich is increasing today with the help of Information technologies and educational platforms. It culminates with a proposal as part of the results obtained from some strategies used that increase the autonomy of thought and action with the aim of building a critical and universal learning process within the competitive requirements within society. It is important to recognize, therefore, how the autonomy and the necessary indicators are carried out for its effective implementation within the change of perspective of higher education.
\end{abstract}

\author{
Autonomous learning, Higher education, Curricular \\ proposal
}

Citation: ROMERO-ROMERO, Yair, ARAOZ-BALTAZAR, Iván, GARCÍA-PÉREZ, María Laura and VÁZQUEZELORZA, Ariel. Autonomous education and its current inclusion in higher education, Journal Health, Education and Welfare. 2019. 3-5: 23-34

\footnotetext{
* Correspondence to Author (email: yair.romero@ conacyt.mx)

$\dagger$ Researcher contributing as first author
} 


\section{Introduction}

Education is one of the factors that most influences the progress and progress of people and societies. That is why it is necessary in every way to achieve better levels of social welfare and economic growth (UNAM, 2019). For this reason some countries have opted for education as a basis for their educational growth; An example of this is Cuba, which according to the World Bank (2019) occupies the first place in terms of investment in the education system with $13 \%$ of its Gross Domestic Product (GDP), followed by Timor Leste with $11.3 \%$ of the GDP, Denmark (8.7\%), Bolivia as the second American country after Cuba with $7.6 \%$ of its GDP, United Kingdom 6.2\%, while Canada and the United States invest $5.4 \%$ and $5.2 \%$ respectively, Mexico, on the other hand, only invest $5.2 \%$ of GDP.

The previous statistics show a correlation between the invested GDP of each country and the results obtained in the PISA test, this test gives us data on student performance at the international level, launched by the Organization for Economic Cooperation and Development (OECD, 2016). The results show that the countries with the highest investment are the countries with the highest score. In the 2015 test, some of the results are the following: Singapore reached the first place in 70 participating countries in terms of reading and math level (BBC, 2016), Denmark, Bolivia, United Kingdom, Canada and the United States. of the first 25 places in the table (OECD, 2016).

In the case of Bolivia, it is not among the first places, but a positive trend has been observed with respect to its previous statistics. In the case of Timor Leste and Cuba they did not participate in this world test, however it was carried out at the regional level by the United Nations Educational, Scientific and Cultural Organization (UNESCO), so 200 thousand students of 16 countries, among which Cuba stood out for obtaining the highest scores (OECD, 2016). The columnist Jorge Eduardo Arellano in his article "Cuba sweeps sciences and mathematics" mentions that Chile, Costa Rica, Uruguay, Mexico and other countries were behind the Cuban titan; while the worst results were produced by Paraguay, Ecuador and Central American countries (Arellano, 2008).
As part of the results of the same PISA test, Mexico occupies the fifty-seventh place in reading and the fifty-sixth place in mathematics of seventy participants (BBC, 2016); In addition to occupying the last places, there is a dropout in Mexico, where according to a study (2015-2016) by the Ministry of Public Education (SEP) every minute 2.2 Mexican children and / or young people quit school. According to the school grade, in primary school the dropout in education was $0.5 \%$, secondary $4.2 \%$, higher average $12.1 \%$ and higher education $6.8 \%$ (Moreno, 2017). In addition to this, in the early twentieth century the massification of schools caused low-performing students to drop out of school or be excluded, which was recommended by "experts" and philanthropists of the moment (Arnaiz, 2019).

The figures are alarming when comparing them between nations, but they are more so when comparing between peoples, for example, the dropout rate in Mexican states is headed by Durango with $16.3 \%$ dropout, Coahuila with $16 \%$ and Zacatecas the $15.9 \%$, in the last places we have Puebla with $9.8 \%$, Tamaulipas with $8 \%$ and finally Jalisco with $3.5 \%$ (Tuirán, 2016)

Fernandez, et. to the. (2013) mentions that the use is due to the conditions of teaching, time management and instructional processes. Other authors add motivation through systematic work (Colmenares \& Delgado, 2008). Arnaiz (2019) establishes a strong criticism of general education practices, arguing that the difficulties many students experience in the education system are not due to their own difficulties, but to certain ways of organizing the centers and teaching. In conclusion, it is identified that school achievement depends largely on the educational strategies implemented (Demuijnck, 2015; Muñoz-Merino, Ruiperez-Valiente, Alario-Hoyos, Perez-Sanagustin, \& Delgado, 2015; Gubbins, 2014; Cárdenas, Zermeño, \& Tijerina, 2013)

That is why it is necessary to redefine learning spaces, so instead of the current teacherstudent relationship, practically handmade, we must evolve into a new curricular structure with a critical change in pedagogical strategies, from the systematic fragmentation of both training process as the teaching-learning object (Almeida-Filho \& Di-Pasquale, 2019). 
Educational institutions should be committed to quality, understood as such, those that manage to reach the teaching goals, in addition to the right to receive an effective education (Arnaiz, 2019), for this a joint planned effort of every institution, intended to lead student learning towards predetermined results; to achieve this, a powerful teaching instrument and a fruitful guide for the teacher, named as curriculum (Casarini, 2013), is of vital importance. This term defined as continuous improvement in the teaching-learning processes (Garbanzo, 2007); Concept that motivated the genesis of this research which aims to "Compare traditional learning strategies against autonomous".

In this regard it is considered that traditional teaching and learning approaches are generally directed at the teacher, so that students are taught an auspicious way of sitting and listening, limiting learning to what is captured in the classroom (Gurudeo \& Machisella , 2018; Asarta \& Schmidt, 2015). These models focus on the figure of the teacher and knowledge is visualized as something created by external; the development and selection of the contents is the exclusive task of the teacher, so the perceptions of the students are not considered. Students are expected to use what they have learned to pass a subject or for the future, however, it is a nonparticipatory system, so students do not build their knowledge or make learning decisions, in addition to being given special emphasis on competition and not cooperation.

Likewise, the student's interaction with the teacher is minimal and generally unidirectional, only to ensure understanding and clarify some doubts. Basically, the classes are based on an explanation and taking notes, which is why great importance is given to memorization and repetition, which prepares the individual for evaluation through a traditional exam (Gargallo, et.al., 2014).

It has often been argued that traditional approaches do not provide the student with valuable learning skills, so there are selflearning methods that are believed to provide students with such skills (Gurudeo \& Machisella, 2018; Martín-Cuadrado, 2011; Molina, et.al., 2003).
Besides that, it has been proven that these self-regulated strategies of time management, metacognition and critical thinking have important positive choreographies in the academic success of students compared to the effects offered by traditional methods (Broadbent \& Poon, 2015). Self-learning is defined by Pintrich (2000) as "an active and constructive process by which students set goals for their learning and then try to monitor, regulate and control their cognition, motivation and behavior, guided and restricted by their objectives and contextual characteristics in the environment". Also, this author considers that there are many self-regulated learning methods, however, they share the following assumptions:

- There is an active constructive assumption, which means that students are active, constructive participants who create their learning process. They actively build their own meanings, goals and strategies from information available in the external environment and in their minds.

- $\quad$ All models assume that students have the ability to monitor, regulate and control certain aspects of their cognition, motivation and behavior.

- $\quad$ Another assumption relates to the ability of people to set learning standards or objectives; in this way they can monitor their progress and with this adapt their cognition, motivation and behavior to achieve them.

Finally, self-regulatory activities are considered to be linked to results such as achievement and performance, although much of the research examines these activities as results in their own right.

This research is carried out in the upper level of the Tehuacán Puebla region, during the four-month period January-May 2019. With what is sought to respond to the hypothesis:

$H_{0}$ : The learning strategy influences the use of students in the study area.

$H_{1}$ : The learning strategy does not influence the achievement of students in the study area. 
The sections of the article are divided as follows. 2. Methodology, the technique of nonprobabilistic sampling is defined (for convenience) and a sample frame of 172 students is obtained, two moments are defined for testing at the beginning (diagnostic evaluation) and at the end (final evaluation), a In the middle of the period a questionnaire is applied where motivational beliefs and selfregulated learning strategies are addressed.

The information obtained is purified, leaving at the end a sample of 112 students, the information is treated by means of Alfa de Cronbach and Chi square. In addition, within this section a methodology is proposed to ensure the quality of the information obtained, with the name "Table of assertiveness of the quality of information". 3 .

Analysis of Results, in this section the selected hypothesis and the statistics obtained are explained and the possible causes of such results are identified. 4. Conclusions, the possible causes of the results obtained are explained, a proposal is made to address the problem identified in addition to expressing the knowledge acquired during this investigation and finally it closes with the bibliographical references in section 5 .

\section{Methodology}

The methodology that was followed was established according to the scope under investigation, Hernández, Fernández \& Baptista (2014) identify 4 types (figure 1): 1. Descriptive, which identifies and specifies the important properties of the group undergoing the analysis. 2. Exploratory, aimed to examine a topic, which could be, not addressed or poorly studied 3 .

Correlational, was intended to measure the degree of dependence that exists between two or more concepts or variables and finally 4. Explanatory study, was aimed at responding to the causes of the event (Hernández, et.al., 2014)

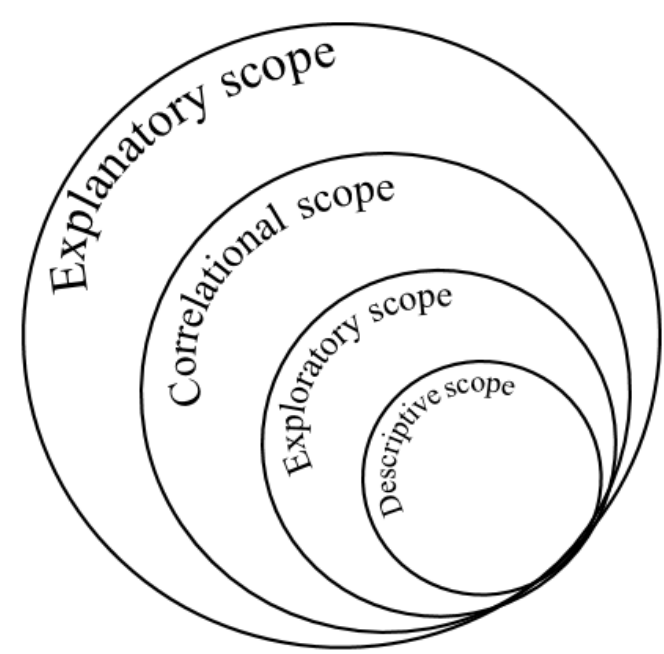

Figure 1 Research process scopes Own Elaboration

\section{Sample Selection}

The methodological process used corresponds to a correlational study, which included the exploratory study and therefore the descriptive study. The corresponding to the latter, in the first stage is the selection of the sample (Figure 2), which was used to achieve non-probabilistic sampling, for convenience, due to the limitations of the equipment (time, limited resources and accessibility to institutions of higher level in the state).

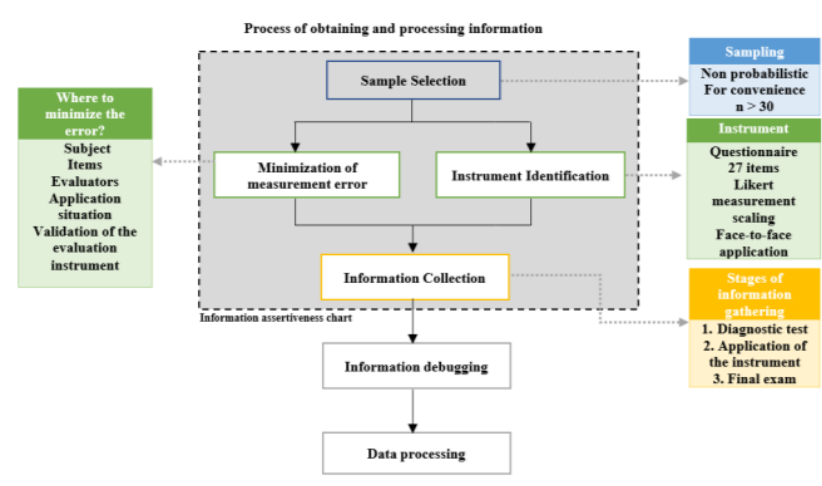

Figure 2 Research process scopes Own Elaboration

Therefore, the unit of analysis was defined, made up of the state of Puebla due to the indexes it presents, where a study carried out by Pérez (2018) mentions that $5.6 \%$ of primary school students are at risk of dropping out of school, with $12.52 \%$ by secondary school students in the 2017-2018 period. In the upper middle level the dropout rate was between 11 and $24.4 \%$ in the 2015-2016 period (INEE, 2019) and at the top level $10.4 \%$ (Gonzales, 2017) 
Due to these indexes, the Secretary of Public Education (SEP) of the state of Puebla has taken actions through its quality policy that seeks to guarantee assistance, permanence and quality of learning, through strategies that promote quality, equality and education equity, based on the continuous improvement of the organization's processes, which in addition to ensuring compliance with regulations, take as a reference the best national and international practices (SEP Puebla, 2019). Due to the foregoing, the state is open to conduct investigations such as the one set forth herein.

Puebla has 217 municipalities, for the feasibility of the study it was decided to select the municipality of Tehuacán, because it is the second largest city in the state, with a population of 274,906 inhabitants and an extreme poverty percentage of 9.74 (SEDESOL, 2014), representative characteristics of the state of Puebla. The university that was studied was selected by the opening it showed and by the research that was carried out; in this document it will be referred to as "university", the official name will be omitted for the handling of information obtained.

The analysis unit corresponded to 172 engineering students (34 women and 138 men) divided into five groups, all of them in the second semester of the subject of mathematics (integral calculus), it was decided to select this subject because it has the degree of failure Highest in the state, in Mexico 70\% of students have failed math in any of the school grades (Excelsior, 2019).

\section{Instrument Identification}

Due to the objectives of this study and an endogenous situation, 27 questions were taken from 55 of the motivational learning strategies questionnaire proposed by Paul R. Pintrich and Elisabeth V. De Groot in their Motivational and Self-Regulated Learning Components of Classroom Academic article Performance which was used to measure students' motivational beliefs and self-regulated learning (Pintrich \& De-Groot, 1990). Said metric divided into 5 sections: 1. Self-efficacy, referred to as the judgments that each individual makes about their abilities, based on which they will organize and execute their acts, so that they can achieve the desired performance (Ornelas, Blanco, Gastelum, \& Muñoz, 2013).
2. Intrinsic value, identified as those actions carried out by the interest generated by the activity itself, considered as an end in itself and not as a means to achieve other goals (Sancho-Álvarez, Jornet, \& Perales, 2014). 3. Cognitive strategy are the ways or ways that help to plan, monitor and review your study process according to your own intellectual abilities to reach the solution of a problem. (Marugan, Martin, Catalina, \& Roman, 2013)

4. Self-regulation, defined as the competence that allows students to activate the learning strategies necessary to achieve the established objectives. Seven major theories about self-regulation can be distinguished: operant, phenomenological, information processing, sociocognitive, volitional, Vygotskian and constructivist (Panadero \& Alonso-Tapia, 2014).

5. Anxiety by evaluation is defined as a set of symptoms grouped in cognitive, psychophysiological and motor responses issued by an individual to school situations that are perceived as threatening and / or dangerous; These can act as an important barrier for the personal, social and academic development of children and adolescents (Martínez, Ingles, \& Garcia-Fernandez, 2013).

\section{Minimization of measurement error sources}

Non-probabilistic sampling is a sampling technique where data collection does not offer all individuals in the population equal opportunities to be selected, in addition to the process being completely subject to the investigator's judgment. One of the most important disadvantages is that the sampling error cannot be measured or calculated accordingly in this investigation, preventive measures were taken to minimize it, which involved the 5 main actors identified in classics such as Anastasi 1954-1990, Nunnally 1970, Brown 1980, Thorndike 1989-1996 (Cervantes, 2005), which are as follows: 1. Subject (students), through the evaluator was given the necessary information in a presentation prior to the evaluation, as was: project objectives and importance of your answers.

On the day of the evaluation, the evaluator explained again the importance of the investigation, as well as the questionnaire instructions. 2. 
Items, a questionnaire of 27 questions was applied in the computer room of the university in a single session, each student assigned to a single computer, the order of the questions was random for each student. 3. Evaluators and teachers, the research team trained the evaluator on the approach to the research problem, objectives and the achievable ones of the project, that is, the importance of the information collected. In addition, the procedures with which the evaluator had to present to the unit of analysis (students) and what kind of information they had to share were made known.

On the part of the teachers, they were asked for collaboration to apply two evaluations, one at the beginning of the semester (diagnostic exam) and another at the end (final exam). 4. Situation of application, it was a strategy that the questionnaire was applied one day that had no deliverables (tasks, exercises), or exams; so that students only focus on answering as timely as possible. 5. Measuring instrument, two desirable characteristics in any measuring instrument are reliability and validity, key aspects of the socalled solidity. Reliability is the accuracy with which a measuring instrument measures what it should measure (Quero, 2010) and the validity according to the dictionary of the Royal Spanish Academy (RAE) (2019) refers to that it is acceptable, robust, strong. Therefore, we sought to measure the reliability and validity of the instrument by means of Cronbach's alpha coefficient.

\section{Collection, purification and treatment of information}

The Cronbach Alpha coefficient estimates the lower limit of the reliability coefficient (Ledesma, Molina, \& Valero, 2002), that is, it is an index used to measure the reliability of the internal consistency type of a scale by evaluating the magnitude at which the items of an instrument are correlated (Oviedo \& Campos, 2005) and expressed as (Equation 1):

$$
\propto=\left(\frac{k}{k-1}\right)\left(1-\frac{\sum S_{i}^{2}}{S_{\text {sum }}^{2}}\right)
$$

Where $k$ is the number of test items, $S_{i}^{2}$ is the variance of the items (from 1..i) and $S_{\text {sum }}^{2}$ It is the variance of the total test (Ledesma, Molina, \& Valero, 2002).
In the case of this investigation $\mathrm{k}$ corresponds to 27 questions, $S_{i}^{2}$ is equal to 17.83 and $S_{\text {sum }}^{2}$ It is equal to 70.29 , replacing it is as follows (Equation 2).

$$
\propto=\left(\frac{27}{27-1}\right)\left(1-\frac{17.83}{70.29}\right)=0.78
$$

Generally, a group of items that explores a common factor shows a high Cronbach's alpha value (Oviedo \& Campos, 2005). That is, on a scale of 0 to 1 , the minimum acceptable is 0.7 and coefficients between the intervals of $(0.7$ $0.8)$ good reliability, intervals of (0.8 -0-9) optimal reliability (González \& Pazmino, 2015); (Domínguez, Villegas, \& Centeno, 2014) (Molina, Aranda, Hernandez, \& Jimenez, 2013); (Except, 2013). Which means that our instrument with an alpha of 0.78 is within the range of good reliability, with this we guarantee that our questionnaire has sufficient reliability and validity and we can use this information to answer our hypothesis.

For the $\mathrm{H}_{0}$ and $\mathrm{H}_{1}$ check, through the application of chi-square in the first instance, a diagnostic test was applied to the total number of students (those who missed the test, their result was omitted) leaving a total of 112 students, later during the semester the strategy was used Selftaught to see the thematic content corresponding to the subject, at the end of the school year a final test was applied, which was carried out in groups according to the grade they achieved (Table 1).

\begin{tabular}{|lr|r|r|r|r|r|r|}
\multicolumn{1}{c|}{} & \multicolumn{7}{c|}{ Score } \\
\cline { 2 - 8 } \multicolumn{1}{c|}{} & $\mathbf{5}$ & $\mathbf{6}$ & $\mathbf{7}$ & $\mathbf{8}$ & $\mathbf{9}$ & $\mathbf{1 0}$ & Suma \\
\hline $\begin{array}{l}\text { Traditional learning } \\
\text { score }\end{array}$ & 0 & 10 & 35 & 45 & 22 & 0 & 112 \\
\hline $\begin{array}{l}\text { Self-regulated learning } \\
\text { score }\end{array}$ & 2 & 6 & 26 & 42 & 30 & 6 & 112 \\
\hline Sum & 2 & 16 & 61 & 87 & 52 & 6 & 224 \\
\hline
\end{tabular}

Table 1 Qualifications Obtained Own Elaboration

Once the grouping of the grades was carried out, the theoretical frequencies f_t were obtained, which are obtained as follows: for 0 of table 1 , the theoretical frequency will be the total of the students who obtained a failing grade (5) In this case, it is 2 times 112 , which is the total number of students who underwent the diagnostic test of traditional learning divided by the total of the data that in this case is 224 , which gives a total of 1 (Equation 3). 
$f_{t}: 0 \rightarrow \frac{(2)(112)}{224}=1$

This procedure continued with each of the data (Table 2).

\begin{tabular}{|l|l|l|l|l|l|r|}
\multicolumn{1}{c|}{} & \multicolumn{7}{c|}{ Score } \\
\hline & $\mathbf{5}$ & $\mathbf{6}$ & $\mathbf{7}$ & $\mathbf{8}$ & $\mathbf{9}$ & $\mathbf{1 0}$ \\
\hline Traditional learning score & 1 & 8 & 30.5 & 43.5 & 26 & 3 \\
\hline Self-regulated learning score & 1 & 8 & 30.5 & 43.5 & 26 & 3 \\
\hline
\end{tabular}

Table 2 Theoretical Frequencies Own Elaboration

The procedure was continued to obtain the chi-square denoted by the sum of the frequency minus the theoretical frequency squared and then divided by the theoretical frequency (Equation 4).

$x_{\text {calculado }}^{2}=\sum \frac{\left(f-f_{t}\right)^{2}}{f_{t}}$

Substituting the data in equation 4 generates as a result $x_{\text {calculado }}^{2}=11.66$, Once we obtained our chi-square, we continued to use the distribution table $x^{2}$, but not before defining that our margin of error is established by 0.05 and the degrees of freedom (v) are obtained through equation 5 .

$v=\left(n^{\circ}\right.$ of rows -1$)\left(n^{\circ}\right.$ of columns -1$)$

Substituting the equation taking into account table 1, it is as follows (Equation 6).

$v=(2-1)(6-1)=5$

Getting finally the $x_{\text {tabla }}^{2}=4.25$; $x_{\text {calculdo }}^{2}=11.66$. Now according to the theory it says yes $x_{\text {calculado }}^{2}>x_{\text {tabla }}^{2} \rightarrow$ null hypothesis is rejected, on the other hand while if $x_{\text {calculado }}^{2}<x_{\text {tablas }}^{2} \rightarrow$ alternative hypothesis is rejected. In our case $11.66>4.25 \rightarrow$ Null hypothesis is rejected.

\section{Analysis of results}

A Cronbach's alpha of 0.78 was obtained which shows the reliability of the instrument. When obtaining $\mathrm{x}^{2}$ the null hypothesis was rejected, that is to say that the alternative hypothesis that tells us is accepted: $\mathrm{H}_{1}$ : The learning strategy does not influence the use of students in the study area.
By shredding the statistics obtained through the evaluations and the questionnaire, the results obtained on self-efficacy show that $40 \%$ of the students who answered do not believe they perform well in class compared to other classmates, nor do they agree on understanding the ideas taught in the course, they are said to not perform class problems well, much less homework, because of this students are aware of receiving a low grade for their performance, in short, they believe they are unable to learn the topics in class (Graph 1 ). $41 \%$ of students report not knowing how their performance is, so we infer that only $17 \%$ believe that they work in and out of the classroom, learning the ideas that the teacher tries to transmit.

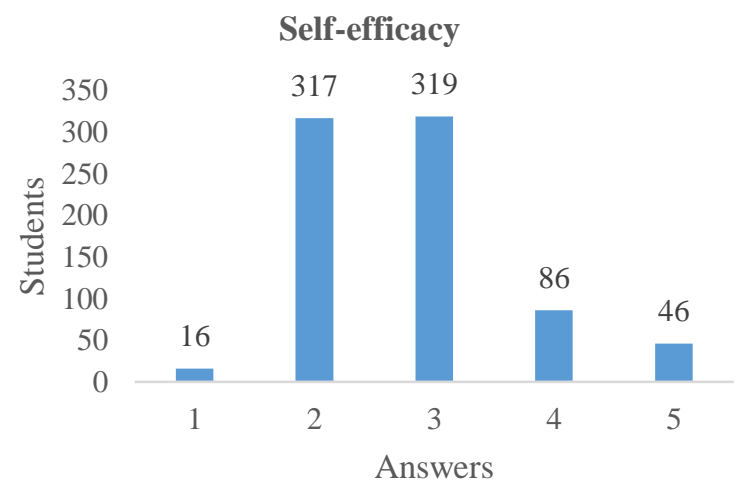

Graphic 1 Results of self-efficacy

Own Elaboration

Regarding the intrinsic value, $54 \%$ of the students do not want challenging subjects that allow them to acquire new knowledge, they do not find it necessary to learn what is taught in class, much less believe it interesting. 28\% say they have no idea what they want to acquire in class or know if it is important for their education. Only $18.5 \%$ mention that they would like topics that demand more of themselves because it would be an important attribution to their education, in addition to believing that the topics in class are interesting (Graphic 2).

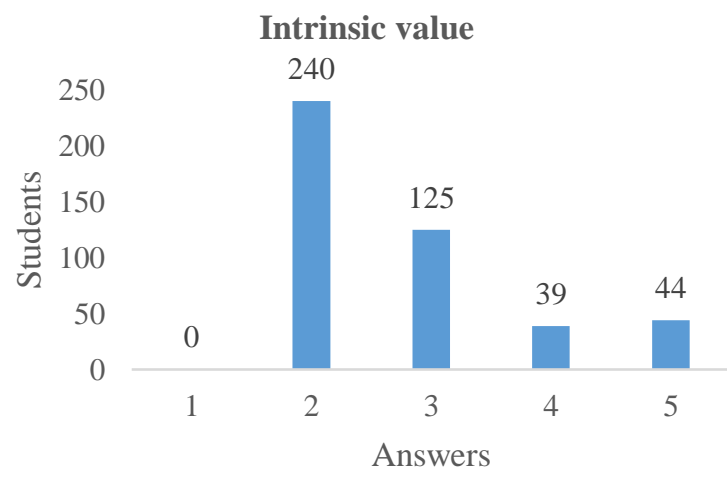

Graphic 2 Intrinsic Value Results Own Elaboration

ROMERO-ROMERO, Yair, ARAOZ-BALTAZAR, Iván, GARCÍAPÉREZ, María Laura and VÁZQUEZ-ELORZA, Ariel. Autonomous education and its current inclusion in higher education, Journal Health, Education and Welfare. 2019 
About the anxiety that students can present in the tests $83 \%$ of them do not cause nervousness to present exams, much less stress, do not reflect on the performance they had during classes. Only 17\% of students cause nervousness and stress during an evaluation or before it (Graphic 3).

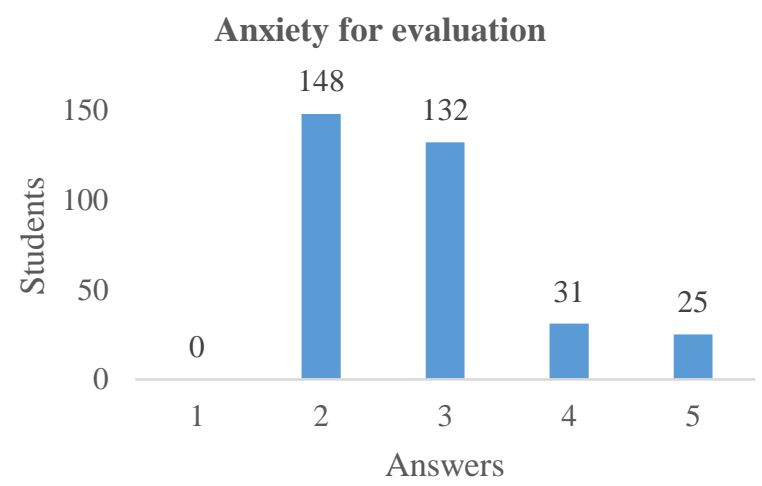

Graphic 3 Results of anxiety by evaluation Own Elaboration

On the cognitive strategy $40 \%$ of the students under study do not review their class notes and much less reinforce them with extra readings. When they do homework they aim to finish it and turn it in instead of remembering and reaffirming what they learned in class. It is difficult for these students to differentiate the main ideas because they do not pay attention to the teacher during class. The students do not have the interest therefore they are not autonomous in their learning (Graphic 4).

$41 \%$ of the students only do what is necessary to accredit the subject, this does not mean that they do it through learning, students state that they reach this goal by copying and delivering tasks seeking to reach the minimum score, $81 \%$ of students do not have the goal of learning only to meet the minimum requirements; Only 18\% are interested in learning and strive to learn in class and reinforce it with the completion of homework, also perform extra activities such as underlining readings, summaries and notes, this percentage says that he always tries to learn what the teacher explains even if he doesn't see meaning or doesn't see the field of application.

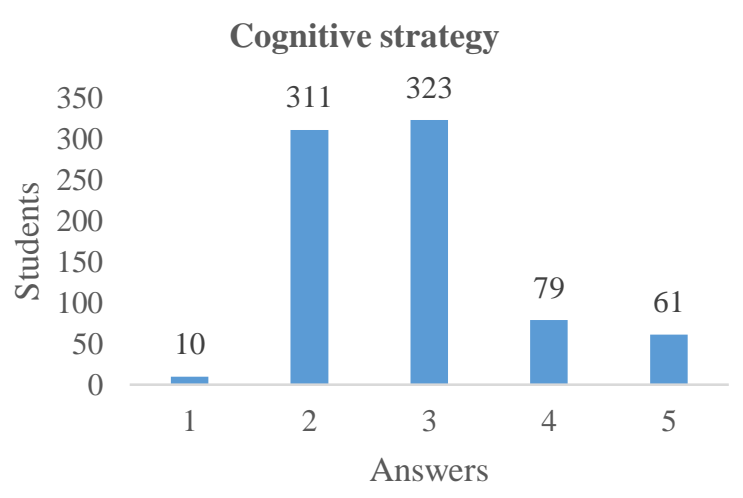

Graphic 4 Results of cognitive strategy Own Elaboration

Regarding self-regulation statistics, $84 \%$ of students, when they see a complicated topic, decide not to pay attention from the beginning, when they are presented with a boring topic to their point of view, they prefer to ignore it, they are not interested in questioning whether they are learning in class nor get good grades, really this percentage of students create only the routine of attending college. $15 \%$ of the students are the only ones interested in attending and learning in class, if they do not succeed they become self-taught doing extra activities in order to achieve knowledge and therefore a good grade, when they reach knowledge they try to see the area of application in your study area (Graphic 5).

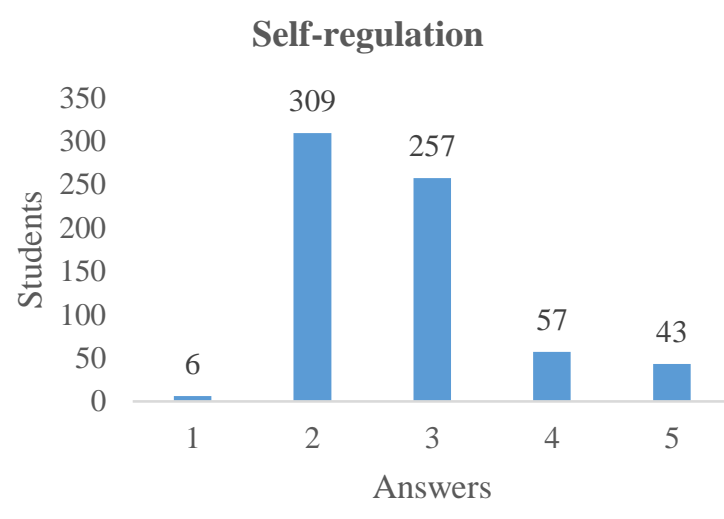

Graphic 5 Self-regulation results Own Elaboration

\section{Conclusions}

$83 \%$ of the students who underwent the tests and that the conventional educational strategy was implemented first and then the autonomous educational strategy did not identify greater academic achievement, in the same way addressing the motivational beliefs, specifically self-efficacy. 
This Percentage of students do not think they are academically effective, about the intrinsic value of the students they do not believe they are capable of obtaining good grades by themselves, they do not believe they are competent to learn and much less apply techniques or methodologies to solve problems. This percentage of students has reached a high degree of conformism, resignation and the way to obtain a passing grade making a zero academic effort, therefore the self-taught strategy is not suitable at the moment to be implemented to this group of students (Graphic $6)$.

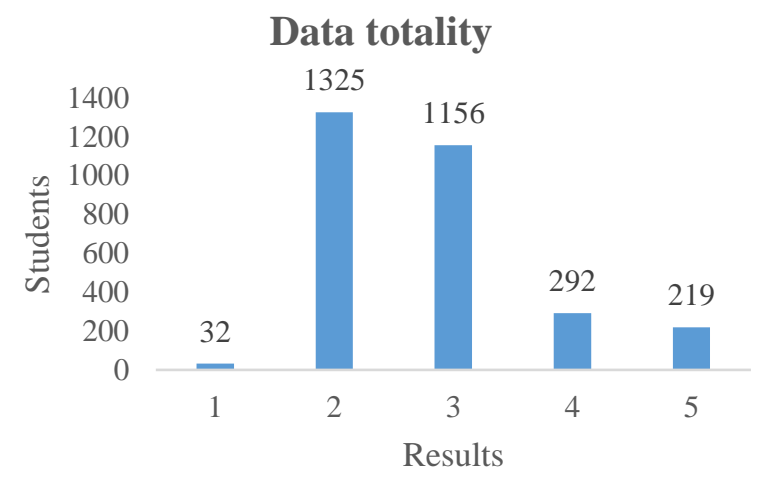

Graphic 6 Data totality

Own Elaboration

This research becomes relevant for the research team because of the learning obtained that was from making the link with the institution and showing the commitment through the results obtained, as is the methodology in which it was worked. However, the most important contribution of this research was for the institution and for government organizations responsible for higher level education, because the problem obtained from low school achievement is due to lack of motivation, security in their abilities and paradigms. of students, this is the vital problem that if treated as a result will improve trivial problems.

It is intended to replicate this research in other universities in different municipalities of the state of Puebla, to identify a problem at the state level, region level or perhaps at the national level.

\section{References}

Almeida-Filho, N., \& Di-Pasquale, M. (2019). El impacto de la reforma Cabanis en la formación histórica de la universidad argentina y en la educación superior en salud. Saludo Colectiva, 1-18.

Arellano, J. (23 de Junio de 2008). Cuba arrasa en ciencias y matemáticas. Obtenido de El nuevo diario:

https://www.elnuevodiario.com.ni/nacionales/1 9518-cuba-arrasa-ciencias-matematicas/

Arnaiz, P. (23 de Septiembre de 2019). LA EDUCACION INCLUSIVA EN EL SIGLO XXI. AVANCES $Y$ DESAFÍOS . Obtenido de https://digitum.um.es/digitum/bitstream/10201/ 67359/1/Leccion\%20Santo\%20Tomas\%202019 $\% 20-\% 20$ Pilar\%20Arnaiz\%20\%280K\%29.pdf

Asarta, C., \& Schmidt, J. (2015). The choice of reduced seat time in a blended course. Internet and Higher Education, 24-31.

Banco Mundial . (5 de Junio de 2019). Estadísticas del mundo real para la comunidad $y$ desarrollo. . Obtenido de https://www.bancomundial.org/

BBC. (2016). Recuperado el 2019, de https://www.bbc.com/mundo/noticias-

38211248

Broadbent, J., \& Poon, W. (2015). Self-regulated learning strategies \& academic achievement in onlinehigher education learning environments: A systematic review. Internet and Higher Educatio, 1-13.

Casarini, M. (2013). Teoría y diseño curricular. México: Trillas.

Ledesma, R., Molina, G., \& Valero, P. (2002). Análisis de consistencia interna mediante Alfa de Cronbach: un programa basado en gráficos dinámicos. Psico-USF, 143-152.

Cárdenas, R., Zermeño, M., \& Tijerina, R. (2013). Tecnologías educativas y estrategias didácticas: criterios de selección. Revista Educación y Tecnología, 190-206. Obtenido de https://dialnet.unirioja.es/servlet/articulo?codig $\mathrm{o}=4620616$ 
Cervantes, V. (2005). Interpretaciones del coeficiente alpha de Cronbach . Avances en Medición , 9-28.

Colmenares, M., \& Delgado, F. (2008). La correlación entre el rendimiento académico y moticación de logro: elementos para la discusión y la reflexión. REDHECS, 179-191.

Cruz, R. (2018). ¿Debemos ir de la educación especial a la educación inclusiva? Perspectivas y posibilidades de avance. . ALTERIDAD. Revista de Educación , 251-261.

Demuijnck, G. (2015). Universal Values and Virtues in Management Versus Cross-Cultural Moral Relativism: An Educational Strategy to Clear the Ground for Business Ethics. Journal of Business Ethics, 817-835.

Domínguez, S., Villegas, G., \& Centeno, S. (2014). PROCRASTINACIÓN ACADÉMICA: VALIDACIÓN DE UNA ESCALA EN UNA MUESTRA DE ESTUDIANTES DE UNA UNIVERSIDAD PRIVADA. Liberabit, 293304.

Excelsior. (26 de Junio de 2019). En México $70 \%$ de los estudiantes ha reprobado matemáticas. Obtenido de https://www.excelsior.com.mx/nacional/enmexico-70-de-estudiantes-ha-reprobadomatematicas/1248182

Fernández, E., Bernardo, A., Suarez, N., Cerezo, R., Nuñez, J., \& Rosario, P. (2013). Predicción del uso de estrategias de autorregulación en educación superior. Anales de Psicología, 865875.

Garbanzo, G. (2007). Factores asociados al rendimiento académico en estudiantes universitarios, una reflexión desde la calidad de la educación superior pública. Revista Educación , 43-63.

Gargallo, et.al. . (2014). Metodología centrada en el aprendizaje. Su impacto en las estrategias de aprendizaje y en el rendimiento académico de los estudiantes universitarios. Revista española de pedagogía, 415-435.
Gonzáles, L. (07 de Julio de 2017). Puebla, sexto lugar nacional en deserción en nivel superior: MIDE. Obtenido de https://www.angulo7.com.mx/2017/01/12/puebl a-sexto-lugar-nacional-desercion-nivelsuperior-mide/

González, J., \& Pazmino, M. (2015). Cálculo e interpretación del Alfa de Cronbach para el caso de validación de la consistencia interna de un cuestionario, con dos posibles escalas tipo Likert. Revista Publicando, 62-77.

Gubbins, V. (2014). Estrategias educativas de familias de clase alta: un estudio exploratorio. Revista mexicana de investigación educativa, 1069-1089.

Gurudeo, T., \& Machisella , P. (2018). Traditional vs Non-traditional Teaching and Learning Strategies - the case of E-learning! INTERNATIONAL JOURNAL FOR MATHEMATICS TEACHING AND LEARNING, 129-158.

Guzmán, J. (2011). La calidad de la enseñanza en educación superior ¿Qué es una buena enseñanza en este nivel educativo? Perfiles educativos, 129-141.

Hernández, S., Fernandez, C., \& Baptista, L. (2014). Metodología de la Investigación. México: McGraw Hill.

INEE. (07 de Julio de 2019). Banco de Indicadores Educativos del Instituto Nacional para la Evaluación de la Educación. Obtenido de https://www.inee.edu.mx/wpcontent/uploads/2019/04/2017_EF_Pue.pdf.

Kurjenoja, A., \& Hernandez, I. (2015). Cultural Processes, Social Change and New Horizons in Education. Procedia-Social and Behavioral Sciences, 3405-3412.

Martín-Cuadrado, A. (2011). COMPETENCIAS DEL ESTUDIANTE AUTORREGULADO Y LOS ESTILOS DE APRENDIZAJE . Revista Estilos de Aprendizaje, 136-148.

Martínez, M., Ingles, C., \& Garcia-Fernandez, J. (2013). Evaluación de la ansiedad escolar: revisión de cuestionarios, inventarios y escalas. Psicología Educativa, 27-36. 
Marugan, M., Martin, L., Catalina, J., \& Roman, J. (2013). Estrategias cognitivas de elaboración y naturaleza de los contenidos en estudiantes universitarios. Psicología Educativa, 13-20.

Molina, et.al. . (2003). Aprendizaje basado en problemas: una alternativa al método tradicional. Revista de la Red Estatal de Docencia Universitaria, 79-85.

Molina, J., Aranda, L., Hernandez, M., \& Jimenez, E. (2013). Utilización del alfa de Cronbach para validar la confiabilidad de un instrumento de medición de satisfacción del estudiante en el uso del software Minitab. Cancún: Eleventh LACCEI Latin American and Caribbean Conference for Engineering and Technology (LACCEI'2013) "Innovation in Engineering, Technology and Education for Competitiveness and Prosperity" August 14 - 16.

Moreno, T. (21 de Agosto de 2017). Deserción escolar, infrenable: SEP. Recuperado el Junio de 2019, de El Universal: https://www.eluniversal.com.mx/nacion/socieda $\mathrm{d} /$ desercion-escolar-infrenable-sep

Muñoz-Merino, P., Ruiperez-Valiente, J., Alario-Hoyos, C., Perez-Sanagustin, M., \& Delgado, C. (2015). Precise Effectiveness Strategy for analyzing the effectiveness of students with educational resources and activities in MOOCs. Computers in human behavior, 108-118.

OCDE. (2016). PISA 2015: PISA Resultados Clave. París: OCDE.

Ornelas, M., Blanco , H., Gastelum, G., \& Muñoz, F. (2013). Perfiles de autoeficacia en conductas académicas en alumnos de primer ingreso a la universidad. Revista electrónica de investigación educativa, 17-28.

Oviedo, C., \& Campos, A. (2005). Aproximación al uso del coeficiente alfa de Cronbach. Revista Colombiana de Psiquiatría, 572-580.

Panadero, E., \& Alonso-Tapia, J. (2014). Teorías de autorregulación educativa: una comparación y reflexión teórica. Psicología Educativa, 11-22.
Pérez, J. (14 de Febrero de 2018). En riesgo de deserción escolar 90 mil 302 alumnos en Puebla. Recuperado el Junio de 2019, de El sol de Puebla: https://www.elsoldepuebla.com.mx/local/enriesgo-de-desercion-escolar-90-mil-302alumnos-en-puebla-949582.html

Pintrich, P. (2000). THE ROLE OF GOAL ORIENTATION IN SELF-REGULATED LEARNING. En M. Boekaerts, P. Pintrich, \& M. Zeidner, Handbook of self-regulation (págs. 451-502). San Diego : Academic Press.

Pintrich, P., \& De-Groot, E. (1990). Motivational and Self-Regulated Learning Components of Classroom Academic Performance. Journal of Educational Psychology, 33-40.

Quero, M. (2010). Confiabilidad y coeficiente Alpha de Cronbach. TeloS, 248-252.

Real Academia Española. (24 de Junio de 2019). Diccionario de la Real Academia Española. Obtenido de http://www.rae.es/

Salvo, L. (2013). Confiabilidad y validez de la escala de impulsividad de Barratt (BIS-11) en adolescentes. Revista chilena de neuropsiquiatría , 245-254.

Sancho-Álvarez, C., Jornet, J., \& Perales , M. (2014). Valor social subjetivo de la educación docencia y resultados escolares. Revista Iberoamericana de Evaluación Educativa, 197207.

SEDESOL. (2014). Unidad de Microregiones Cédulas de Información Municipal. Recuperado el 2019 de Junio, de Secretaría de Desarrollo Social:

http://www.microrregiones.gob.mx/zap/datGen erales.aspx ?entra $=$ nacion\&ent $=21 \&$ mun $=156$

SEP Puebla. (26 de Junio de 2019). Política de la calidad. Obtenido de Gobierno del Estado de Puebla. Secretaría de Educación Pública: $\mathrm{http}$ ://sep.puebla.gob.mx/quines-somos/politicade-calidad

Silva, C. (2018). Capacidad para la libertad. Modelo participativo de desarrollo comunitario y reorientación de los procesos formativos en núcleos sociales marginados. Zona Próxima, 6881. 
Tuirán, R. (2016). Movimiento contra el Abandono Escolar. México : Secretaría de Educación Pública.

UNAM. (05 de Junio de 2019). Importancia de la educación para el desarrollo. Obtenido de UNAM

http://www.planeducativonacional.unam.mx/C AP_00/Text/00_05a.html

UNESCO. (05 de Junio de 2019). La educación transforma vidas. Obtenido de UNESCO: https://es.unesco.org/themes/education 